\title{
Indonesia's State Enterprises: from State Leadership to International Consensus
}

\author{
Yasmin Sungkar \\ Center for Political Studies \\ Indonesian Institute of Sciences
}

\begin{abstract}
The survival of state-owned enterprises and continued investment by the state was assisted by high rates of economic growth in Indonesia throughout the 1980s. The currency crisis in the region, which began in mid-1997, destroyed the expectation that rapid growth would continue. In this climate, the loss-making state companies were a serious financial burden, and privatisation has been promoted as a quick solution. It appears that the crisis reintroduced momentum for reform in the huge state-enterprise sector. In response to IMF pressure and its own fiscal difficulties, the government took several measures to reform the state sector. The economic crisis provided a catalyst because it forced the government to assess more seriously the value of state companies. There was an urgent need to sell state-owned assets to relieve the state budget when economic recovery slowed. This paper examines the efforts to reform the state sector during ten years of Reformasi, including the debate over privatisation and the emergence of strong resistance to reform. It appears that the crisis has strengthened the hand of reformers seeking to privatise the state sector. However, despite the logic of government efforts to reform inefficient state companies, there has been a battle with each step towards privatisation.
\end{abstract}




\section{Introduction}

State enterprise is a universal phenomenon in the economic systems of developed and developing countries. From the 1950s to 1970s, international aid donors, such as the IMF and the World Bank, encouraged the establishment of public enterprises in developing countries. The expansion of state-owned enterprises became a major characteristic of developing economies and these companies were seen as the main pillars of development. Furthermore, the tradition of direct governmental participation and control of the economy also prevailed in these developing systems (Gupta 2000: 132). During the 1950s, development economists viewed state intervention in the economy as essential and encouraged the belief that government coordination of economic activities led to successful economic development. In lateindustrialising countries in particular, state enterprises were often established to undertake investment where the private sector was weak, or in specific missions to serve public needs.

In this view, public interests were best served by placing the economy in the hands of the government. Therefore, a number of public enterprises were purposely created to generate revenue, redistribute income, create jobs, promote regional development, develop infrastructure, fill gaps where the private sector was either unwilling or unable to enter, nationalise foreign enterprises in the public interest, strengthen economic sovereignty against multinationals and protect national security through direct intervention in areas of strategic importance (Bienen and Waterbury 1989: 618). Most developing countries set up public enterprises to fulfil as many of these objectives as possible.

State-owned enterprises had grown to play a central role in the national economy of Indonesia after independence. But despite their major economic importance to the nation, state enterprises have generally been poorly managed, often operating more as instruments of the bureaucracy, well-connected business groups or the military rather than as independent businesses focused on generating profits. The survival of state-owned enterprises and continued investment by the state in heavy industry and high-technology projects was assisted by high rates of economic growth throughout the 1980s and much of the 1990s. The currency crisis in the region, which began in mid-1997, destroyed the 
expectation that the rapid growth would continue. The government's fiscal policies were in tatters and deficits soared. In this climate, the financial burden of supporting state companies increased greatly.

State companies have always been sheltered from serious public examination and the government's stated intention in the late 1980s to reform state enterprises came to nothing. However, the continuing effects of the 1997 currency crisis included sustained momentum for reform in the huge state-enterprise sector. In response to IMF pressure and its own fiscal difficulties, the government took several measures to reform the state sector. The economic crisis provided a catalyst because it forced the government to assess more seriously the value of state companies. Although reform in the public sector initially aimed at increasing longterm efficiency, with Indonesia in its fifth year of crisis, there was an urgent need to sell state-owned assets to bolster the state budget. Hence, the sale of state enterprises became a priority from 2002 .

But could privatisation be effectively carried out in this climate-where the economic crisis later became a political and social crisis as well? Reforming Indonesian state enterprises will certainly need strong political will as well as state capacity. The purpose of this paper is to examine the efforts to reform Indonesian state enterprises. The debate over privatisation and the emergence of strong resistance to reform will be the theme of this paper. This paper also takes a close look at the dispute over PT Semen Padang, a cement company in West Sumatra province, which illustrates the contending forces at play in privatisation. It appears that the dispute strengthened the hand of reformers seeking to privatise the state sector. With fiscal pressures on the budget, the need to divest the state of the expense of funding large projects and state enterprises, and the pressure to deregulate further, it would seem that privatisation was inevitable. Yet why has it been so hard for the government to make real changes in the state enterprise sector-dismantling state ownership and moving towards international consensus? Why has progress has been uneven - and why and from whom is there still resistance? Despite the logic of government efforts to reform inefficient state companies, privatisation efforts have faced roadblocks in all directions. These are related issues that will also be addressed in this paper. 


\section{A Brief History of State Enterprises in Indonesia}

State-owned enterprises in Indonesia were originally set up by the colonial Dutch administration in the late $19^{\text {th }}$ and early $20^{\text {th }}$ centuries. With the arrival of independence, the 1945 Constitution provided a legal basis for nationalisation and the new national government took over several enterprises. The extension of public enterprise was accomplished through the nationalisation process, which began in December 1957. The bulk of the economy was taken over by the state authority from the Dutch administration. In addition to many commercial, industrial, and banking firms, more than four hundred agricultural estates were taken over in this single phase of nationalisation (Paauw 1967: 13839). By the end of Sukarno's rule in 1966, state enterprises had grown to become the dominant force in the domestic economy. Unfortunately, state companies had also become increasingly misused as sources of collusion: their managers, many from the military, had little or no business expertise. The arrival of Suharto's New Order government was expected to improve Indonesia's economic efficiency and to see the reform of the state sector. But the ability to perform efficiently was handicapped further when state enterprises were manipulated for political purposes - to pay off political cronies or to serve the personal ambitions of those in charge. Moreover, with the dramatic increase in oil prices in the early 1970s, the urgency diminished for Indonesia to push through reforms of its state enterprises. In fact, reform of state enterprises went into reverse with the government increasing its proportion of ownership in the domestic economy. Economic nationalists were able to pursue their expansionist industrial goals without having to follow sound and professional management practices.

In the 1980s, Indonesia had over 200 state enterprises, including several large companies that dominated strategic sectors of the economy. ${ }^{1}$ These included Pertamina (the state oil company), Garuda (the state airline), state

1 In Indonesia, state enterprises operate mainly under two legal forms - Persero and Perum. A Persero is a profit-oriented shareholding company with limited liability, in which the State holds all or part of the shares. They account for the vast majority of state enterprises (87 per cent in 1992). Perums (11 per cent) are enterprises with a public utility function, and are wholly owned by the State. In addition, there are three special-status state enterprises, including the oil and gas company, Pertamina (World Bank 1993: 140). 
commercial banks, and various telecommunications companies. Most enterprises were in industry (23 per cent), followed by agriculture (19 per cent), finance (16 per cent), public works (10 per cent), transport ( 9 per cent), and ten other sectors (22 per cent). State enterprises produced an estimated 15 per cent of GDP with total assets of about Rp200 million in 1991 (World Bank 1993: 140). Another measure of size is the amount of capital participation in state enterprises by the central government. This peaked at Rp592 billion in 1983-84, but decreased to a low of Rp91 billion by 1986-87 because of budgetary constraints caused by falling oil prices (Pangestu and Ahmad 1989: 232). Capital participation from the government was high during the oil boom years and functioned as subsidies to these state enterprises. Government subsidies to state enterprises in the form of capital participation and loans declined with the fall in oil revenue. Only strategic industries would continue to receive capital participation by the government. Some sectors stopped receiving any subsidies — notably state enterprises in agriculture, mining, banking and trade.

During the New Order era, control of about 200 state enterprises was scattered among different government departments. Although many enterprises had strong affiliations with their technical ministries, this subordinate position made them unable to function ideally as efficient commercial enterprises. Most companies were unable either to make significant contributions to state coffers or to provide competent service to their customers. Mismanagement and poor regulation left over half of state enterprises significantly underperforming. Ultimately, this lack of capacity by the state to supervise these enterprises coupled with pressure for reform led to the establishment of a new state enterprises ministry in early 1998, which had the potential to do what could not be done before.

A new government regulation, Peraturan Pemerintah No. 50 of 1998, shifted the management of state firms, previously scattered among different state departments, into the hands of the Minister of Empowerment of State Enterprises, Tanri Abeng. This new ministry, in Suharto's seventh cabinet, assumed authority over the Ministry of Finance, which represented the government as a stake holder, and 
the technical ministries, which previously managed state companies. Suharto chose Abeng because of his long experience and demonstrated abilities in senior management of national and multinational companies. Despite being well qualified, the task given to Abeng was a daunting one in the face of vested interests in the technical ministries as well as in the managers of the companies themselves.

At the start of the financial crisis, most Indonesian state-owned enterprises had been poorly managed for a prolonged period of time and shown very low rates of return on investments and on equity, less than the cost of capital. Until the end of 1997, with total assets of Rp461.6 trillion (US\$57.6 billion), the average return on investment and return on equity of state enterprises was respectively 3.5 per cent and 9.6 per cent, which showed the low level of asset utilisation and the high level of production costs. These low returns were the result of the monopoly position of many industries coupled with the lack of responsibility demonstrated by the management of these enterprises. Many top management positions were patronage appointments made with no regard for qualifications. Many managers had close relations with bureaucrats in the technical departments that controlled state enterprises (Kompas 27 April 1998). State companies in Indonesia also were notorious for their corrupt corporate bureaucracies. Often, large quantities of government subsidies found their way into the pockets of private citizens. One of the most notorious cases involved state-owned bank PT Bank Pembangunan Indonesia, which lost US\$650 million in 1993 because of collusion between members of the bank's board and a businessman (The Nikkei Weekly 10 November 1997: 20).

To prevent collusion and corruption, the new Ministry of State Enterprises applied good corporate governance and an improved incentive system. The ministry's initial investigation revealed that 173 contracts showed evidence of corruption, collusion, or nepotism. Seventy-nine contracts were cancelled, 25 contracts were retendered or renegotiated, 59 contracts were further investigated, and 10 contracts were continued under new terms (Ministry of State Enterprises 1999: 52). Furthermore, to anticipate the effect of the new policies, Abeng set up an independent 
Public Policy Committee on 28 September 1998. ${ }^{2}$ The committee was expected to provide opinions and constructive criticism of the new plans and policies made by the Ministry of State Enterprises (Ministry of State Enterprises 1999: 42, 44). This effort could be seen as an initial step to create a democratic and transparent system in public policy making.

Furthermore, the Ministry of State Enterprises took important steps toward restructuring, increasing profitability, and privatisation. Within 18 months, Abeng restructured state banks, agro-industry companies, the state airline and the state electricity company. The profit margin in 1998 increased from 14.7 per cent to 17.4 per cent (Strategi November 1999: 25). He also managed to sell government shares in five out of twelve companies intended to be privatised. This brought in US $\$ 1.035$ billion into the state budget, including US\$122.1 million from selling 14 per cent of the shares of cement company PT Semen Gresik (Strategi November 1999: 19). However, this is not to say that privatisation was popular in Indonesia. As we will see in the following sections, there were and continue to be many challenges, internal and external, facing reform in the state-owned sector.

In 2006, there were 161 state enterprises with total assets of about Rp772 billion. Seventy-eight per cent were in competitive industries, 6 per cent in monopolies, and the rest were in combinations of competitive and monopolistic markets. Even though most of these enterprises were in competitive industries, just 11 companies were responsible for 79 per cent of the total profit contribution to the state. Large numbers of state enterprises contributed only small profits to the state budget; of 25 lossmaking companies, 11 represented 84 per cent of the total loss to the state (Ministry of State Enterprises). The government planned to reduce the number of unprofitable state companies from 28 in 2007 to 11 in 2008 and total losses from Rp2.94 trillion (around US\$323 million) to only Rp0.23 trillion for the same period (Jakarta Post 21 April 2008). This is a very ambitious goal for a government that has proven unwilling and unable to manage its state companies for decades. Within

2 In formulating policies toward the state sector, the Ministry of State Enterprises not only considered profit and efficiency but also the public welfare. The independent committee involved fourteen members from various groups: academic, press, parliament, military, and business. (Ministry of State Enterprises 1999: 41-42). 
the ten years of Reformasi, little progress has been made in improving the performance of state enterprises.

\section{Reasons for Privatisation ${ }^{3}$}

It is generally assumed that the private sector is more efficient than the public sector. The myth holds that what the public sector can do, the private sector can do better. Since the 1980s, privatisation has been strongly recommended to most countries where key sectors have been dominated by public enterprises. In the early and mid-1980s, external price shocks led to marked deterioration in macro-economic performance globally, abruptly igniting fiscal and debt crises. In this context, loss-making public enterprises were a particularly conspicuous drain on government resources, and privatisation was promoted as the best answer to the problems of these institutions (Sundaram 1995: 2). When a public enterprise loses its comparative advantage in a given sector of activity there is a case for privatisation. However, the most forceful factor in favour of some privatisation seems to lie in the poor performance recorded by public enterprises across the board.

Although poor financial results have prompted governments to reconsider the role and performance of public enterprises, it is difficult to expect that privatisation will or should occur quickly. Ramanadhan cites three reasons for this. First, it is difficult on political and ideological grounds. Second, the deficits of some public enterprises are calculated in support of social goals. Third, many of the enterprises can improve financially if, irrespective of ownership, operating criteria were rationalised (Ramanadham 1987: 201). In the case of companies chronically in the red with no prospects of recovery, this paper argues that privatisation is a solution to make firms more transparent and accountable. It will force under-performing companies to increase efficiency before their shares

3 According to Presidential Decree No. 122/2001, privatisation means a transfer of part of state enterprise control to private hands through an initial public offer, direct sale to strategic partners, sale to workers, or via other appropriate means. According to Gupta, privatisation, in the present context, refers not only to the transfer of ownership of public assets but also the abandonment of some of the functions that the government had taken upon itself in the recent past. Reduction in the size and role of the public sector and an emphasis on price and markets as allocative mechanisms also amount to privatisation (Gupta 2000: 138). 
are seen as attractive in the capital market.

Growing realisation of the burden that state enterprises put on the Indonesian government has led to several policy changes since 1988 . Together with other structural reforms, the government put more effort into improving the operational and financial performance of state enterprises. Imposed measures include changes in corporate legal status, mergers, revised management contracts, pursuit of joint ventures, public share issues and liquidations. The government also introduced a system of annual performance reviews of financial and managerial achievements (World Bank 1993: 141). Studies of public enterprise performance in developing countries indicate that many countries operate state enterprises that show low profitability or continuing financial losses. ${ }^{4}$ The reasons often put forth are inadequate planning and poor feasibility studies; lack of skilled managers and administrators; centralised decision-making; state intervention in the daily operations of the firm; unclear and multiple objectives; and political patronage (Pangestu 1989: 233). These same reasons have often been cited to explain inefficiencies in Indonesian state enterprises. The usual justification for continued subsidisation of state enterprises is the familiar infant industry argument. Subsidisation is needed until such time as the enterprise becomes efficient and profitable. The perception of a net welfare loss and the practical need to reduce subsidies to inefficient state enterprises because of tight budgetary conditions were pushing the Indonesian government to look with more favour at formerly unattractive alternatives, including market liberalisation and privatisation.

In the face of increased privatisation and globalisation of the economy, the era of extensive expansion of public enterprises has come to an end. However, few governments have willingly undertaken the divestiture of state enterprises. Rather, they are forced to do so because of the hopeless performance of state-owned enterprises in general. In most developing countries a state-owned enterprise offers many opportunities

4 However, many state-owned enterprises flourished, including Hong Kong's Mass Transit Railway, Singapore's Mass Rapid Transit, Malaysia's Petronas and Indonesia's Indosat. They were at or near the top of the 1998 annual list of Asia's top companies (Far Eastern Economic Review 4 March 1999: 49). 
for corruption because of its highly bureaucratic structures. Their ability to perform efficiently is affected further when they are manipulated for political purposes. Gradually, state companies become a substantial drain on national treasuries and the costs involved are monumental (Gupta 2000: 135). Faced with poor performance of the state enterprises and plagued by the growing need for more and more funds, starting in the 1980s, many governments began looking for answers. They found privatisation a timely solution.

Privatisation movements gained momentum during the 1980s, during which many western and non-western societies tried to follow the privatisation lead of the United Kingdom (Gupta 1996: 38-51). ${ }^{5}$ Although efficient operation of these UK enterprises was a legitimate concern, often the more pressing motive for privatisation was the fiscal drain on government resources (Christiansen 1989: 597). In the 1990s, privatisation came to be recommended on the basis that private ownership is more efficient in terms of resource allocation than public ownership. Privatisation allows governments to divest loss-making enterprises and improve efforts towards economic efficiency (Gupta 2000: 137). However, in most countries, privatisation involved not only an economic device but also a political strategy. The first Minister of State Enterprises, Tanri Abeng, who originally came from the private sector, learned an important lesson in handling the public sector in Indonesia. As he said, 'My paradigm was running corporations, not political organisations. [...] But not in public corporations. I had to spend considerable time dealing with politics, which I was not prepared for, initially' (Asiaweek 22 January 1999: 31).

There are many reasons for adopting privatisation, ranging from immediate financial gains, economic efficiency, improved competition and wider share-ownership to political popularity. As such, each government has to work under various economic, political and sociocultural constraints. In Indonesia, the universal trend in the $1980 \mathrm{~s}$ toward deregulation and privatisation may have provided one source

5 A study estimated that some 1400 privatisation efforts were underway at the end of 1987. Over 80 developing countries were involved, including China, Tanzania and Algeria, which had traditionally favoured a prominent role for the state in the economy (De Walle 1989: 601). 
of inspiration. But the sharp drop in oil prices, which led to shrinking government revenues, was the main motivation for the government to renew calls for efficiency in state enterprise performance as well as a public debate on the issue of privatisation. Nevertheless, the presidential decree on the reform of state companies and numerous subsequent ministerial rulings issued during the 1980 s and early 1990 s to implement the decree accomplished little. These rulings have remained virtually unenforced for ten years, defeated by strong vested interests.

In fact, the government's reform efforts until 1997 had focused on improving efficiency and productivity, rather than on a change in ownership. But non-commercial activities given to state enterprises damages their capacity to improve efficiency. For instance, the use of state enterprises to stabilise or subsidise prices, the use of strategic industries to develop advanced technology, and the required support from state enterprises for small firms and cooperatives - all contribute to serious inefficiencies in resource use (World Bank 1993: 143). ${ }^{6}$ Despite the enthusiasm of liberal reformers, privatisation has moved slowly. Only a few state firms; cement, tin, telecommunications were privatised before the economic crisis. The government paid serious attention to this public sector as privatisation became a more important element of economic reform in Indonesia after the crisis.

Although structural reform is a long-term solution and the issue of deregulation is not directly connected with the currency crisis, many Indonesian economists believe that market distortions contributed to the large depreciation of the rupiah in 1997. Three issues covered in the structural reforms are foreign trade and investment, deregulation and privatisation, and the social safety net. The decisions in the January 1998 package to discontinue the special tax, customs and credit privileges granted to the national car company, and the budgetary and extra-budgetary support for the national aircraft company, and to eliminate the clove monopoly, had been awaited for some time, and were viewed as a signal of the government's commitment to economic

6 The small business support scheme, for which state enterprises are expected to allocate 1 to 5 per cent of their after-tax profits, requires them to devote staff and financial resources outside their main sphere of activities, and is unlikely to provide the most efficient mechanism to support small firms (World Bank 1993: 143). 
reform. The reforms were politically sensitive, because they went to the heart of the problems of cronyism, corruption and collusion. IMF officials said that Indonesia must reduce its budget deficit, bolster its banking system, and halt several expensive infrastructure projects that mainly benefited Suharto's family but they also acknowledged that these steps were likely to be politically painful. In this context, a series of struggles over economic policy evolved. On one hand, there was the IMF and its Western backers and, on the other, Suharto, Vice-President Habibie, the politico-business families and the major conglomerates. But it is probable that both sides realised their importance in producing a credible program, capable of restoring the confidence not only of the international market but also of the Indonesian public.

The plunge of Asian currencies gave the IMF far greater power over economies in the region than it would normally have had. Involvement in the Indonesian crisis appears to have led the IMF to formulate a 'new' approach in which structural reforms became an integral part of any reform program. A broader set of structural adjustments, including privatisation of state enterprises, reduced state regulation of the economy and reduced public expenditures, were urged by international agencies and lenders, including, most prominently, the World Bank, the Asian Development Bank and the International Monetary Funds. This strategy had been adopted initially over a decade in response to high levels of indebtedness among some countries in Southeast Asia. The privatisation plan, which has been on the national agenda for a long time, is now becoming part of a reform package in which continued aid is conditional upon demonstrable privatisation progress. This is not to say that there is no criticism from liberal reformists within the country.

In the case of Indonesia, structural reform had been part of the national agenda for decades but its implementation has stalled in the face of powerful vested interests. The chances of successful implementation of structural reforms were assumed to be improved if they became part of a broader program to overcome the crisis. In November 1997, the government set out an ambitious strategy of structural reform, aimed at bringing the economy back to a path of rapid growth, by transforming the 'high-cost economy' into one that would be more open, competitive, 
and efficient. This created an impression that the IMF imposed the structural reform program on Indonesia. In turn, this sparked a nationalist backlash that still influences the policy directions of Indonesia's national development in the post-crisis era. This counter-reaction is evident in the case of the accelerated program of privatisation. A clear framework was established for the management and privatisation of government assets (either through share flotation or negotiated enterprise sales). This included criteria for determining whether state enterprises should be closed, restructured, or fully privatised, along with transparent sales processes that maximise the return to government and treat all bidders equally (IMF 15 January 1998). However, the sale of state assets to foreigners is not publicly popular.

A crucial debate is going on in many developing nations about the proper role of the public sector in economic development and on the pros and cons of privatisation. Although some believe in shedding loss-making public enterprises, others believe in restoring them. In some countries, the sole reason for privatisation seems to be to acquiesce to international aid donors' demands without any regard to the fundamental political and economic issues involved (Heald 1990: 15). In such countries, there is more rhetoric than actual implementation of privatisation. However, the crisis increased the momentum for reform of the huge public-enterprise sector in Indonesia. The government announced several measures to reform state sectors in response to IMF pressure and its own fiscal difficulties.

The economic crisis provided a catalyst for the government to assess more seriously the value of state companies. In need of foreign exchange, Indonesia pledged to sell large stakes in state-owned enterprises, although it was unclear how much interest there would be from foreign investors. The privatisation program was part of the reform package the government agreed to with the IMF ${ }^{7}$. Under the terms of a US\$43 billion bailout led by the IMF, Indonesia was committed to divest stakes in 12 state-owned enterprises. The problem would be finding buyers.

7 The IMF became involved in arranging a bailout for the Indonesia economy in October 1997 and subsequently pressured the government into accepting a wide range of market-based economic reforms, including the privatisation of several state enterprises (Van Zorge Report on Indonesia 20 November 2001: 7-8). 
Drained by the 70 per cent plunge in the rupiah in less than a year, many state-owned companies' finances were gloomy. Potential investors also faced problems with managerial control. It was not clear what voice a foreign investor would have in running a state company. Analysts also expressed caution that funds from healthy state-owned companies could be drained to support the weaker ones (Asian Wall Street Journal 31 March 1998: 1).

The government also announced it would sell more of its shares in five publicly listed firms to foreign investors to raise badly needed funds to finance the government's inflated spending. ${ }^{8}$ However, the government would still hold at least 51 per cent of the shares in each state company. Responding to the question of whether retaining the majority of the share is still significant, Tanri Abeng, then first Minister of State Enterprises said, 'It depends on the type of the industry, it is necessary for vital industries, but not for other industries where the private sectors became strong enough such as the cement industry' (Gatra 25 April 1998: 70). The proceeds were to be used to strengthen the state budget as well as to support the government balance of payments. The crisis also strengthened the position of domestic and foreign interests which hoped to see Indonesia move towards more liberal economic policies and away from state interventionism. Yet the problem was not only in finding buyers - many state enterprises' finances were gloomy — but also in dealing with strong domestic resistance. The following section will examine some of the different forces opposing privatisation, making clear that economic recovery cannot be effected without political and social reform as well.

\section{Contending Forces Over Privatisation}

The most important reason for privatisation is constant dissatisfaction

8 The five publicly listed firms in which the government holds the majority share are domestic telecommunication operator Telkom (75.8 per cent), international telecommunication operator Indosat (65 per cent), nickel and gold miner Aneka Tambang (65 per cent), tin miner Tambang Timah (65 per cent) and cement producer Semen Gresik (65 per cent). 
with the performance of public enterprises in general. ${ }^{9}$ It is argued that public enterprises have contributed to budget deficits. Privatisation can reduce government expenditure by abolishing or reducing subsidies given to them. The government can also expect to gain extra revenue from enterprises that make profits after they have been privatised. As such, privatisation can promote competition and efficiency as well as save the limited resources of the government (Gupta 2000: 23-24). Thus, as economic conditions have deteriorated and fiscal crises have become common in the developing world, government patience with public enterprises has worn thin. However, mere unhappiness with public enterprises is not sufficient for their privatisation and does not automatically lead to an ideological change favouring reform - at least not in Indonesia. Indonesian state enterprises have been mismanaged and have served as breeding grounds for corruption, collusion, and nepotism for decades. These vested interests are formidable obstacles to reform. Abeng argues that 'Privatisation would help to ensure that these businesses were protected from future interference by corrupt politicians looking to raise funds for personal or party political reasons' (Van Zorge Report on Indonesia 20 November 2001: 8). Thus, besides the efficiency motive - turning loss-making into profit-making - the Ministry of State Enterprises has also set out to curtail the abuse of state enterprises and to free them from vested interests and their cronies.

In the UK, once the political decision was taken to divest state enterprises, the key questions related to financial matters. In developing countries, the key question was who the potential buyers would be. In deciding who should be allowed to buy assets and equities, various political, economic and socio-cultural factors had to be kept in mind (Gupta 2000: 25). The question of privatisation remains highly controversial in Indonesia, including within government and legislative circles. Some have expressed fears that selling state assets will in the long run turn Indonesians into second-class citizens in their own country. Others

9 As De Walle says, public enterprises lose money, or do not make as much money as they should, given that they often benefit from privileged access to capital, various subsidies, and protection from domestic and foreign competition. Some of their weaknesses are unclear, multiple or contradictory objectives, bureaucratic interfering, centralised decision making, managerial incompetence and excessive personnel costs (De Walle 1989: 603). 
believe, on the contrary, that privatisation will turn non-performing businesses into healthy companies by running them in an entrepreneurial and profit-oriented manner. As Christina $\mathrm{M}$ Rantetana remarked, relating to PT Terminal Petikemas Surabaya [Surabaya Container Terminal], 'Even before visiting the terminal in August, I already held the view that privatisation is beneficial if it is handled professionally, and if the company is acquired by the right investors. It should not make any difference whether the investors are local or foreign' (Van Zorge Report on Indonesia 8 October 2002: 10) ${ }^{10}$.

Privatisation is likely to face serious hurdles in an economic system plagued by the domination of special interests. Consequently, the government has to work under various economic, political and sociocultural constraints. A serious challenge to Indonesian government authority is best illustrated by the case of cement producer Semen Gresik's privatisation plan. ${ }^{11}$ The dispute includes provincial politicians, company managers, and community leaders in West Sumatra. The government has been trying to sell its stake in Semen Gresik, in part to raise much-needed government revenues, but the plan has been held up by strong domestic opposition based on fear of foreign control. This case demonstrates how the central government has to compromise with the interests of local elites, local management and employees but still maintain the interest of foreign investors.

Extensive privatisation programs simply cannot be implemented where financial resources are scarce, capital markets are fragile, the private sector weak and over-protected and foreign investors disliked. Political uncertainties can also derail privatisation. Despite good intentions, political weakness can result in poor or no implementation at all.

10 Christina M Rantetana, a legislative member from the TNI-Police faction, is one of eight members of the special committee that visited PT TPS in August 2002 to observe how the privatisation process has affected the terminal's operations. In 1999, P\&O Australia Ports Ltd. acquired a 49 per cent stake in TPS.

11 Semen Gresik was formed by the merger of three companies in 1995, but local land disputes at the time were not resolved. With the onset of the financial crisis in mid-1997, the government announced in March 1998 that Semen Gresik would become the first state-owned company to be privatised. The initial negotiations were aimed at offering 35 to 40 per cent shares to a strategic investor. 
Moreover, disagreements over which public enterprises are to be sold may result in long delays. Legal provisions, such as assuring employment to workers, also pose a serious challenge to the privatisation movement (Gupta 2000: 43-44). Even when a change in asset ownership occurs rather than the liquidation of an enterprise, workers and unions often fear that economic efficiency will be achieved through job reduction (Bienen and Waterbury 1989: 622).

At best, the transition from the public to the private sector is not likely to be without disagreement. The most important obstacles to privatisation have related to implementation rather than reform proposals, and in most cases very little thought has been given to the design and process of reform implementation. This neglect on the part of policy makers can prove to be extremely costly because reforms usually provoke the greatest opposition once the implementation program is commenced (Bery 1990: 1129). Admittedly, privatisation is a complicated process. De Walle pointed to two kinds of constraints that have constantly damaged privatisation efforts: first, a number of implementation issues have proven prominent, second, political constraints on reform-minded governments reduced the speed of privatisation execution (De Walle 1989: 608).

Despite the pressure and opportunities to reform the Indonesian public sector, resistancetoreform grew intandem with theseincreasing pressures. Powerful vested interests, inside and outside state enterprises, tried to maintain the status quo. They mobilised support from workers, unions and the local community to exploit nationalist sentiment in opposing the sale of state enterprises to foreign concerns. The result was that few attempts to privatise state enterprises ran smoothly, especially when plans were made to negotiate direct placements with foreign strategic partners. There are several cases that demonstrate the struggle between the pros and cons of privatisation. In 1998, the government cancelled an MOU signed by the Minister of State Enterprises and Ispat International because the rush to privatise the state steel company, PT Krakatau Steel, provoked heated debate. In 2001, legislators nearly cancelled the sale of the state-owned palm oil plantation, PT Perkebunan Negara, to a Malaysian company; they asserted that assets like these should remain 
under Indonesian control. In 2002, the sale of a government stake in the state-owned telecommunications company, PT Indosat, to Singapore Technologies Telemedia, was heavily criticised, partly because of the lack of transparency and suspected irregularities.

The real issue seems to be the overall incapability of the administrative and decision-making system to plan ahead and execute plans authoritatively. Too often a lack of political support derails reform in Indonesia. So too does inadequate planning and preparation. The fact that there is little clear-cut legislation on privatisation causes additional difficulties. ${ }^{12}$ Usually, planners misjudge political opposition and the political resources needed to counter that opposition. Reform packages that collapse during the course of execution can be costly in terms of politics and economics (Bery 1990: 1130). Privatisation has seldom gone according to plan in Indonesia. Worse, for every battle won, there is no guarantee that the victory will serve as a precedent. Indeed, the opposite may be the case: opponents fight even harder the next time around. Privatisation's endless war with deep-rooted, vested interests within state enterprises and those who benefit from them, means that every privatisation proposal is subject to several barriers that have little or nothing to do with purely nationalistic or patriotic concerns, though opponents often cloak their objections in such rhetoric.

What else makes privatisation difficult in Indonesia? Part of the blame falls on fluctuating global stock markets. More important is opposition from Indonesia's powerful labour unions. But the biggest obstacle is often Indonesia's unreceptive legislature. Officials managing the sale of government companies are very aware that lawmakers will attack them if the sale price of state assets is considered too low, meaning they sometimes ask for more than the market will pay. Legislators are worried about jobs being lost and unemployment increasing. But beyond such legitimate concerns about privatisation, executives say some politicians are also unwilling to surrender the political influence that comes with controlling big companies. Indonesia's failure to achieve reform so far has

12 It was not until July 2002 that Minister of State Enterprises, Laksamana Sukardi, submitted a draft law on privatisation to the House of Representatives. The House formed 28-member special committee to review the bill. The bill was finally endorsed at the House plenary session on May 27, 2003. 
weakened the government's authority and undermined the government's credibility in the eyes of foreign donors and investors, making sustained economic recovery harder, if not impossible, to achieve.

\section{Case Study: PT Semen Padang}

Just under four months after taking office, President Megawati Sukarnoputri faced the first serious challenge to her authority. Her dispute with provincial politicians, corporate chiefs and community leaders in West Sumatra showed the limit of central authority across the Indonesian archipelago.

Based in West Sumatra, PT Semen Padang is Indonesia's oldest cement producer. It was founded under Dutch occupation in 1910 under the name of Nederlanddsch Indische Portland Cement Maatschppij (NV NIPCM). When it was set up, the company took over and used traditional lands occupied by residents of the village of Indarung (Tempo 23-29 October 2001). Compensation was made to affected villagers at the time. On 15 September 1995, Semen Gresik, one of the largest cement manufacturers in Indonesia, acquired Semen Padang and Semen Tonasa (South Sulawesi). In 1998, Semen Gresik was privatised so that the share composition became as follows: the government with 51 per cent, Cemex - a Mexicobased cement giant - with 25.53 per cent; and the public with 23.47 per cent. The government was given a so-called put option - the right to sell its remaining 51 per cent stake to Cemex within three years.

The government needed to sell its stake in Gresik, in part to raise much-needed revenues, but the plan was held up by strong domestic opposition based on fears of foreign control. The planned sale of Semen Gresik-Padang-Tonasa was further complicated when the West Sumatra Regional House of Representative and the local government unilaterally took over Semen Padang in November 2001. The provincial authorities demanded that Semen Padang be spun off as a separate entity to detach it from the proposed sale to Cemex.

The sale was vital if the government were to meet its $\$ 650$ million privatisation target in 2001, necessary to reduce its budget deficit. For 
that reason, the government proposed a new version of the deal to appease local authorities and others who objected to the original sale plan. Under the new scheme, the government would sell its majority in Gresik but use part of the proceeds to buy back 51 per cent stakes in units Padang and Tonasa, where opposition to the sale has been strongest. Hence, Cemex would have minority stakes in the two units. But this step failed to appease local authorities in Padang. This regional rejection was supported by Gresik's workers in East Java province, the location of the main plant.

The cement industry worldwide had begun consolidating and Cemex wanted a foothold in Indonesia - the world's fourth most populous country and a market where cement consumption remains low by international standard. Cemex, the world's number-three cement producer and already the holder of a 25.5 per cent equity stake in Gresik, had hoped to take the additional 51 per cent as part of a broader plan for expansion in Asia. Therefore, control of Semen Padang, which accounts for about a third of the combined companies' total production, was crucial to Cemex's plans in Indonesia. Ownership of Semen Padang and Semen Tonasa would give it a nationwide distribution network and the ability to use economies of scale and technological know-how to bring down production costs and boost profits.

Some countries may be forced to adopt privatisation as required by international aid donors, others may promote it merely for obtaining immediate economic gains. Since the 1997 economic crisis, Indonesia was pushed to privatise for both reasons. However, there are particular groups who have enjoyed tremendous economic power for some time so that privatisation efforts by the government have significant resistance from these various interest and pressure groups. Opposition to privatisation comes from the ministry concerned, the management of the public enterprise and from particular elements of the bureaucracy, who are not wanting to lose the special benefits and privileges they are accustomed to. As such, substantial obstacles may occur at the policy-making and at the implementation stages. Thus, although state enterprises are widely recognised as inefficient businesses, this does not automatically bring about a broad-based support for handing them over 
to private interests. In one example of how public and private interests overlap in Padang, Afrizal, the chairman of the provincial assembly committee in charge of economics, also acts as an intermediary in the supply of coal to Semen Padang. Though he was strongly opposed to the Cemex bid, Afrizal insisted that there was no conflict of interest between his role as a state legislator and as a businessman, and that his only purpose was 'to help the local people' (FEER 15 November 2001).

Invoking the 'local people's interest' is often misused by local elites to maintain their benefits coming from state companies. Titi Lubuk, deputy chairperson of the West Sumatran assembly, said that the takeover was an example of 'people's power'. In her view, the factory was built on communal lands and customary law prohibits it from being handed over to foreigners. The provincial governor, Zainal Bakar, asserted that Semen Padang was to West Sumatra what the Taj Mahal was to India and Volkswagen was to Germany - a symbol of pride that cannot be sold to foreigners (FEER 15 November 2001). In fact, local community leaders have lobbied parliament in Jakarta to allow the deal with Cemex to go ahead, as long as outstanding local issues were resolved. They demanded a settlement of the land dispute, as well as commission payments equivalent to 1 per cent of the company's annual revenue to support the local community. Furthermore, they even issued a statement calling on the government to fire the director of Semen Padang for dishonesty and causing financial loss to the company and to the community. This battle demonstrates one of many constraints in implementing privatisation in Indonesia, the lack of prior consultation by the central government with local people and provincial governments.

Supporters of the deal with Cemex dismissed the concerns claimed by West Sumatran authority. The real issue, said Basril Basyar, publisher of the newspaper Padang Pos, was that the deal with Cemex threatened the ability of local elites to use the state-owned company as a cash cow and a source of patronage. With nearly 3000 workers, Semen Padang is the largest employer in the province. According to Basyar, coal mining interests are only the tip of the iceberg. Semen Padang's management worried that control by Cemex would bring greater scrutiny of business 
practices that had gone unchecked for decades. 'I think the government's intention to sell the stakes is for everyone's interests, for the nation's and workers'... The decision won't change. Cemex will stay as the majority shareholder in Gresik,' Sukardi said at the time (Reuters 13 December 2001). 'If the central government bows to pressure, the next time round Riau will want to control Caltex and Papua will want to control Freeport,' said Mohamad Sadli, an economics minister under former President Suharto. He further said, 'The central government must win, or pretty soon there will be no central government' (FEER 15 November 2001). This privatisation process could be seen as a real test case for the government in demonstrating its authority. Allowing its assets to be taken away without legal grounds could further destroy confidence of foreign and domestic investors.

Cemex's mistake was in underestimating the power of local elites to undermine central government policy even when this trend was becoming clear. It relied too heavily on the weight of economic logic and neglected the importance of local politics in Indonesia since the collapse of Suharto's rule. It appeared that the Megawati government's commitment to the deal, and to the entire privatisation program, was lukewarm at best. She said privatisation often led to other issues that needed to be carefully dealt with first. In this context, privatisation policy would be conducted cautiously (FEER 15 November 2001). The Minister for State-owned Enterprises, Laksamana Sukardi, called the takeover illegal, but he did not outline what the government had planned in response. Mohammad Sadli suggested that Indonesia was in a state of 'semi-anarchy'. In the meantime, the leaders of the anti-Cemex group in Padang felt that their battle was already won. If the government of Indonesia could not find a way to reassert its authority in West Sumatra, other ambitious local leaders would begin to stake their claims to state assets. For instance, in Sulawesi, legislators demanded that the Semen Tonasa plant also be spun off. The move on Semen Padang presented not only legal and budget pains for the central government, but also threatened to further damage Indonesia's image in the eyes of the international business community.

After years of struggle, officials at Semen Gresik finally managed to take 
over Semen Padang management in 2003. This takeover came following a ruling issued by the Padang District Court, ordering the former directors and commissioners of Semen Padang to leave the company's headquarter and allow new management appointed by Gresik's shareholders to take over. The case drew significant notice because it was seen as a test case for how the central government would respond to regional governments demanding control over local industries. Power in the public sector and in the bureaucracy moved sharply from central to local government with the rushed introduction of regional autonomy laws in 2001. The volatile mix of the state's privatisation program with this decentralisation took a heavy toll and the West Sumatra province of Padang became a testing ground for the inevitable battle between central and local government. But after a five-year war, the government was defeated by a collective force of provincial legislatures, local interest groups and company management, and decided to abandon privatising its own asset. Prompted mainly by the catastrophe at Semen Padang, in late 2003 Cemex filed an arbitration case with the International Center for the Settlement of Investment Dispute in Washington, DC against the Indonesian government (Jakarta Post 2 July 2005). At the end, Cemex sold its 25 per cent stake in publicly listed PT Semen Gresik to local business conglomerate Rajawali in June 2006. Cemex's decision to quit, after eight years of frustrated attempts at operation, hardly presents Indonesia's investment climate in a good light. Semen Padang highlights all that can go wrong with privatisation in Indonesia, raising concerns among investors and donors about the difficulty of buying key assets and the country's overall economic reform program.

\section{Conclusion}

The role of the state as entrepreneur, at its peak in the 1940s and 1950s, diminished during the 1980s and 1990s. Policy makers in developing countries tied state enterprises to ambitious goals, but few were achieved and state enterprise performance was often disappointing. Economic liberalisation, deregulation and privatisation became the topics of national and international discourse on political economy. The OECD, the IMF and the World Bank played important roles in propagating the ideology and rhetoric of global privatisation. Many developing countries introduced privatisation programs because they were driven 
by the need to improve state enterprise performance, or to stop a cash drain. In some cases, these countries were pressured by organisations such as the World Bank and the IMF (Wortzel and Wortzel 1989: 634). However, an acute debt crisis pushed the privatisation debate in most developing countries and that alone put it on their national agendas.

Once a public enterprise has been in public hands for a significant time, there develops a strong inertia that tends to favour the status quo (Haggard and Kaufman 1988: 25-6). In the case of Indonesia the state has had a major role in the workings of the economy and readjustment will not come easily. Indonesia has a large economy and the government is involved in almost every sector. It appears that moves to deregulate have been more reactive and ad hoc rather than part of a systematic plan. The motive for privatisation after the crisis is for immediate financial gain, rather than for ideological purposes. Major shifts in the role of government intervention in the economy are linked closely with economic and political change.

The prospects of privatisation are further damaged by political and economic instability. Privatisation is, as Starr notes, a 'fuzzy concept that evokes sharp political reactions' (Starr 1988: 1101). The success of a privatisation program depends on the popular support enjoyed by a government. If a privatisation program enjoys a high level of acceptance within all the major political parties, or among the people, it may succeed. If it is seen as favourite program of the ruling head of the government or the finance minister, with little political or popular support, the smallest change in the political situation may crumble the support base needed for a sustained reform (Gupta 2000: 146). In Indonesia, political uncertainties slow the pace of economic reform in general and with privatisation programs in particular. It further creates strong stakeholder opposition from some members of the House of Representatives, state company management, workers, unions, and a public not yet convinced of the benefits of privatisation. There are also legal uncertainties in the process as illustrated by the case of Semen Gresik and its subsidiary, Semen Padang. Without strong leadership from the government, a consensus has yet to form. 
There is a close association between power, wealth and politics in all societies, and these factors constitute the political culture of a given society. Furthermore, implementation of complex socio-economic reforms requires a great deal of political expertise and administrative skill (Gupta 2000: 47). The political effect of privatisation is more difficult to predict. In Indonesia, competent government executives, competent entrepreneurial managers, and capital are all in short supply. Realistically, the government simply cannot and will not be able to privatise as many state enterprises as it desires. Nor will it be able to complete far-reaching privatisation programs within the time period targeted. The initial goals for state enterprise privatisation have not been achieved in any of the past six years.

Moreover, the government will be constantly thwarted by opposition unless it can muster enough political will to convince stakeholders, such as the House of Representatives, regional governments, state enterprise management and employees, and the public at large about the advantage of shifting assets and risk away from the public to the private sector. No government can implement privatisation programs and policies without the active cooperation of top bureaucrats, legal experts and financial analysts. Quite paradoxically, liberalisation, deregulation and privatisation simply cannot be carried out successfully in developing economies in the absence of a strong state. We should not forget that privatisation has many non-economic dimensions - political, historical, and social. Achieving real progress requires the commitment of all sectors of Indonesian society, not just its economists.

\section{References}

\section{Books and Journals}

Bery, SK. 1990. 'Economic Policy Reforms in Developing Countries: The Rule and Management of Political Factors'. World Development. Vol. 18. No. 8.

Bienen, Henry and Waterbury, John. 1989. 'The Political Economy of Privatization in Developing Countries'. World Development. Vol. 17. No. 5: 617-632.

Christiansen, Robert E. 1989. 'Introduction on Privatization'. World Development. Vol. 17. No. 5: 597-599.

De Walle, Nicolas Van. 1989. 'Privatization in Developing Countries: A Review of the Issues'. World Development. Vol. 17. No. 5: 601-15. 
Gupta, Asha. 2000. Beyond Privatization. London: Macmillan Press.

Haggard, S and Kaufman, R. 1988. The Politics of Stabilization and Structural Adjustment. Prepared for the NBER Project on Developing Country Debt. Cambridge, MA: NBER.

Heald, David. 1990. 'The Relevance of Privatization to Developing Countries'. Public Administration and Development: 10.

Paauw, Douglas S. 1967. 'From Colonial to Guided Economy', in Ruth T. McVey (ed.). Indonesia. New Haven: Hraf Press.

Pangestu, Mari and Habir, Ahmad. 1989. 'Trends and prospects in Privatization and Deregulation in Indonesia'. ASEAN Economic Bulletin, March: 224-241.

Ramanadham, VV. 1987. Studies in public Enterprise: From Evaluation to Privatization. London: F Cass.

Reformasi BUMN yang Berorientasi pada Penciptaan Nilai Melalui Pendekatan Kesisteman. 1999. Jakarta: Kantor Menteri Negara Pendayagunaan BUMN/ Badan Pembina BUMN.

Starr. P. 1988. 'The Meaning of Privatization'. Yale Law and Policy Reviews. Vol. 6: 1101-36.

Strategi, November 1999.

Sundaram, Jomo K (ed.). 1995. Privatizing Malaysia: Rents, Rhetoric, Realities. Boulder, Colorado: Westview Press.

Wortzel, Heidi Vernon and Wortzel, Lawrence H. 1989. 'Privatization: Not the Only Answer.'. World Development. Vol. 17. No. 5: 633-641.

\section{Newspaper and Magazine}

Asiaweek, 22 January 1999.

Far Eastern Economic Review, 4 March 1999 and 15 November 2001.

Gatra, 25 April 1998.

Kompas, 27 April 1998.

Reuters, 13 December 2001.

Tempo, 23-29 October 2001.

The Asia Wall Street Journal, 31 March 1998.

The Jakarta Post, 2 July 2005.

The Nikkei Weekly, 10 November 1997.

Van Zorge Report on Indonesia. Vol. III. No. 20, 20 November 2001.

Van Zorge Report on Indonesia. Vol. IV. No. 17, 8 October 2002.

World Development Report. World Bank. 1993.

\section{Website}

International Monetary Fund. 1998. Indonesia Memorandum of Economic and Financial Policies. (World Wide Web document, URL: http://www.imf.org/ external/np/loi/011598.HTM. 15 January 1998).

Ministry of State Enterprises (World Wide Web document, URL: http://www.bumn. go.id/masterplan.html) 